\title{
The Regulation and Biochemical Action of Natural Fungicides in Tobacco
}

by

Hans-Jochen Eberhardt

Verband der Cigarettenindustrie

Königswinterer Str. 550

53227 Bonn

\section{SUMMARY}

The biochemical interactions between the tobacco plant and a fungal pathogen are complex and poorly understood. Upon infection, the fungus overcomes the natural defence mechanism of the host by the lytic activity of enzymes and by suppressing the hypersensitive reaction of $N$. tabacum. The ability of the tobacco plant to resist a fungal attack is based on macroscopic properties and the biosynthesis of natural fungicides.

The physical and biochemical character of the leaf surface (e.g. trichome exudates, cuticular components) may prevent the fungus from entering the organism. Constitutive natural fungicides such as phenolics and terpenes operate as enzyme inhibitors, or impair the germination of the fungal spores. Newly synthesized polysaccharides of the cell wall of leaf cells may delay the penetration of the fungus. Lignification of the surrounding cells occurs to protect the healthy tissue against attack. Toxic substances created during the melanization process of the tobacco plant can destroy the fungal cells. Biosynthesis of natural fungicides, such as phytoalexins, pathogenesis-related proteins and proteinase inhibitors is induced by exogenous or endogenous elicitors. These active protection systems may interfere with the fungal metabolism. Phytoalexins and patho-

* Received: 22th March 1995 - accepted: 18th September 1995 genesis-related proteins are highly effective defence responses which offer a broad spectrum of variability and resistance against a fungal infection. New strategies for engineering crop protection are based on these defence systems.

\section{ZUSAMMENFASSUNG}

Die biochemischen Wechselwirkungen zwischen Tabakpflanze und Pilzpathogen sind vielfältiger Natur und bisher nur unzureichend erforscht. Im Falle einer Infektion durchbricht der Schadpilz die natürliche Verteidigungsbarriere des Wirtes durch die Aktivierung lytischer Enzyme und Suppression der hypersensitiven Reaktion von N. tabacum. Die Fähigkeit der Tabakpflanze einen Schadpilz abzuwehren ist einerseits durch die makroskopischen Eigenschaften des Tabakblattes festgelegt, andererseits beruht sie auf der Biosynthese fungizid wirkender Substanzen, die bei Bedarf von der Pflanze produziert werden. Die physikalischen und biochemischen Charakteristika der Blattoberfläche (z.B. Trichomexudate, Bestandteile der Cuticula) können ein Eindringen des Pilzpathogens in den Organismus verhindern oder zumindest erschweren.

Konstitutiv vorhandene natiirliche Fungizide, wie Phe nole und Terpene, agieren dabei als Enzyminhibitoren oder beeinträchtigen bereits das Auskeimen der Pilzsporen. Neu synthetisierte Polysaccharide der Zellwand 
verzögern ein weiteres Vordringen des Pilzes. Die Lignifizierung des umgebenden, noch gesunden Gewebes schützt die nicht befallenen Zellen vor den Pilzattacken. Toxische Substanzen, die während der Melanisienungsvorgänge von der Tabakpflanze gebildet werden, können die Pilzzellen abtöten. Die Biosynthese natürlicher Fungizide, wie Phytoalexine, 'pathogenesis-related proteins' und Proteinase-Inhibitoren, wird durch exogene oder endogene Elicitoren induziert. Diese aktiven Abwehrsysteme können in den Metabolismus des Pilzes eingreifen. Die Phytoalexine und die 'Pathogenesis-related' Protein-Bildung sind hochwirksame Verteidigunsreaktionen der Pflanze, die ein großes Ausmaß an Variabilität aufweisen und die Resistenzausbildung gegenüber dem Pilzpathogen fördern. Neue Ansätze zur Schädlingsbekämpfung beim Tabakanbau versuchen diese natürlichen Abwehrsysteme zu nutzen.

\section{RESUME}

Les interactions biochémiques entre la plante de tabac et le champignon pathogène sont très complexes et peu investiguées. En cas d'une maladie, l'agent pathogène romp le système de défense naturel de l'hôte au moyen de l'activité d'enzymes lytiques et de la suppression de la réaction hypersensitive de $N$. tabacum. L'habilité de la plante de tabac à résister aux attaques fongicides provient des propriétés macroscopiques des feuilles et de la biosynthèse de substances fongicides développées le cas échéant.

Le charactère physique et biochimique de la surface de la feuille (tels que d'exudates de trichomes, composants cuticulaires) empêche ou complique au moins la pénétration du pathogène dans l'organisme.

Les champignons constitutifs naturels tels que les phenoles et les terpènes agissent comme inhibiteurs enzymatiques ou ils compliquent la sporulation. Des polysaccharides nouvellement synthétisés dans la membrane de cellule des feuilles retardent la progression de la pénétration du champignon. La lignification du tissu ambiant encore saint semble exercer un effet protecteur sur le tissue non atteint par les champignons. Les substances toxiques formées pendant le processus de mélanisation de la plante peuvent détruire les cellules toxiques. La biosynthèse de champignons naturels tels que les phytoalexines, les proteines PR ('Pathogenesis Related Poteins') et les inhibiteurs de la protéinase, est induit par des eliciteurs exogènes et endogènes. De tels systèmes de protection actifs peuvent influencer le métabolisme du champignon. Les phytoalexines et les protéines $P R$ constituent avec leur variabilité et leurs formation de résistances envers les infections fongicides un système de défense très efficace de la plante. De nouvelles stratégies employées dans la lutte contre les parasites sont basées sur ces méchanismes.

\section{INTRODUCTION}

Plants have developed effective defence mechanisms as a protective measure against the attack of pathogens and predators. Among the majority of known microorganisms, only a few have the ability to infect living plants, particularly Nicotiana tabacum. On the one hand, the ability of the tobacco plant to resist viral, bacterial or fungal pests and insects depends on the structure and characteristics of the leaf surface. On the other hand, there are active protection systems which could be induced, and cause the biosynthesis of a multitude of different substances with toxic effects for the invaders. In this way, the attack of a pathogen can often be repulsed. However, certain microorganisms or insects can succeed in overcoming the natural defence strategies and thereby damage or even destroy the host.

In the case of a fungal infection, the pathogen subsists from the products of the plant metabolism and grows inside the tobacco tissue, forming new spores at the end of the generation cycle. In this so-called "compatible interaction" (host susceptible, pathogen virulent) between the plant and the parasite, the fungus eludes the tobacco cells' surveillance mechanisms, or even suppresses their manifestation of resistance (15).

However, an "incompatible interaction" (host resistant, pathogen avirulent) elicits a rapid induction of the defence mechanisms of the plant. A central element of this incompatible interaction and increase in resistance is the "hypersensitive response" (HR), which involves a localized cell suicide around the infection site and the triggering of a number of inducible defences. Usually necrotic lesions are formed, indicated by small brown spots on the leaves. This local and rapid cell death causes encapsulation of the pathogen and prevents its further penetration into the adjacent, unifected tissues of the host. At the same time, the cells in the immediate vicinity of the necrotic zone begin synthesizing fungistatic and fungitoxic compounds.

However, the HR of the plant is not limited to fungal infections. Many induced resistance responses are also observed during attacks by viral and bacterial pathogens and insects. Moreover, the ability to kill a penetrating fungus or other pests is not only a property of the tobacco plant, but is also a characteristic feature of numerous other plant families. Specific antifungal antibiotics such as the tobacco sesquiterpene phytoalexins are often produced. Thus the HR can be defined as an unspecific reaction of the plant to a penetrating pathogen or an invertebrate invader. By the rapid death of the infected or damaged plant cells, disease resistance mechanisms are triggered, which can be activated in stages at different times and in different parts of the plant. As a key event of this unspecific defence response, a rapid increase in free and activated oxygen species has been reported, which 
seems to be the beginning of a signal transduction pathway for initiating the plant's specific protection systems (e.g. biosynthesis of phytoalexins and lignins), a process of decisive significance for the development of disease resistance in tobacco (6).

Not only local defence mechanisms at the infection site are activated by an avirulent, fungal pathogen; distal tissue parts remote from the infection site contribute to eliciting resistance as well. This inducible "systemic acquired resistance" (SAR), which is based on the expression of several different genes encoding antimicrobial activities, also implies an improved protection against subsequent infestations with the same or even unrelated pathogens. It is suggested that a systemic signal produced at the infection site (e.g. salicylic acid) is translocated to distal, healthy plant cells and induces SAR gene expression (53), including five or more families of pathogenesis-related genes. The so-called "pathogenesis related proteins" (PRP) are members of this gene family and some of them possess fungitoxic properties (17).

The following review gives an account of the manifold molecular interactions between the tobacco plant and a fungal pathogen and will attempt to describe the biochemical and regulative mechanisms linked to $H R$ and SAR. In addition, various strategies for using the natural fungicides of tobacco for plant protection against fungal and other microbial pathogen attack are discussed.

\section{BIOCHEMICAL ACTION AND INDUCTION OF RESISTANCE}

\subsection{Aggressive strategies of the fungus}

Phytopathogenic fungi have developed extensive metabolic reactions and biochemical processes to overcome the natural resistance of a host plant and to make the plant material accessible to the fungi as a source of energy. These strategies are:

The expression of specific receptors and secretion of certain molecules for recognizing and fixing spores at the plant surface (56). In the case of Phytophthora nicotiana (Black shank), glycoproteins (MG: $42 \mathrm{kDa}$ ) promote the linkage of a pathogen at the leaf surface of Nicotiana tabacum.

- The production of extracellular enzymes (e.g. cutinase, cellulase, hemicellulase, pectinase, proteinase; Figure 1) stimulate the penetration of the fungus and its active metabolic compounds into the plant tissue (15).

- The biosynthesis of phytotoxic substances (toxins), which interfere with the primary metabolism of the host cells. This leads to disruption of the plant's biochemical pathways according to the molecular mode of action of the toxins. However, the released toxins can often trigger a defence reaction of the plant. Phytophthora species for instance - with the exception of Phytophthora nicotianae - secrete the socalled elicitins (e.g. cryptogein, parasiticein, capsicein), which certainly cause necrotic lesions on the tobacco leaf surface, but also act as signal molecules and induce hypersensitivity and resistance in the plant $(14,59)$.

Elicitins are very similar holoproteins. Their molecular weight is close to $10 \mathrm{kDa}$ and their primary structures show homology greater than $75 \%$ (26). Elicitins from various fungal species exhibit different levels of biological activity and toxicity. Because of their action as signal molecules they are classified as exogenous elicitors. Exogenous elicitors are usually non-toxic cell wall fragments of a fungus (e.g. chitosans, 1,3-B-D-glucans) released by the hydrolytic activity of the plant enzymes. In contrast, endogenous elicitors (e.g. oligogalacturonides) derive from the cell wall of the host (15). They are split off by degradative enzymes of the fungus and can induce phytoalexin accumulation and other resistance mechanisms (Figure 1).

- Suppression of the existing inducible defence responses of the plant by deactivating molecules or enzym systems of the fungus after elicitor treatment or microbial attack (Figure 1). Some fungi possess the ability to neutralize the detrimental effects of the tobacco phytoalexins on their metabolism by the enhanced activity of cytochrome $P$ 450-dependent enzymes (52). Another suppressant effect on the plant's defence responses can be produced by the release of water-soluble, suppressively acting glucans of fungal origin; these glucans impair the formation of reactive oxygen species which are required for eliciting hypersensitive cell death (40).

\subsection{Defence responses of the tobacco plant}

\subsubsection{Structural components of resistance and constitutive natural fungicides.}

For an effective colonization of a host plant, the epidermal outer wall and the deposited layers of cutin and waxes must be penetrated, except in cases where the fungus infects the plant organism directly through stomata or damaged tissue. The plant cell wall, like the lipophilic layers of cutin and epicuticular waxes, is a natural structural barrier which prevent the penetration of the great majority of microorganisms. Nevertheless, some fungal and bacterial 


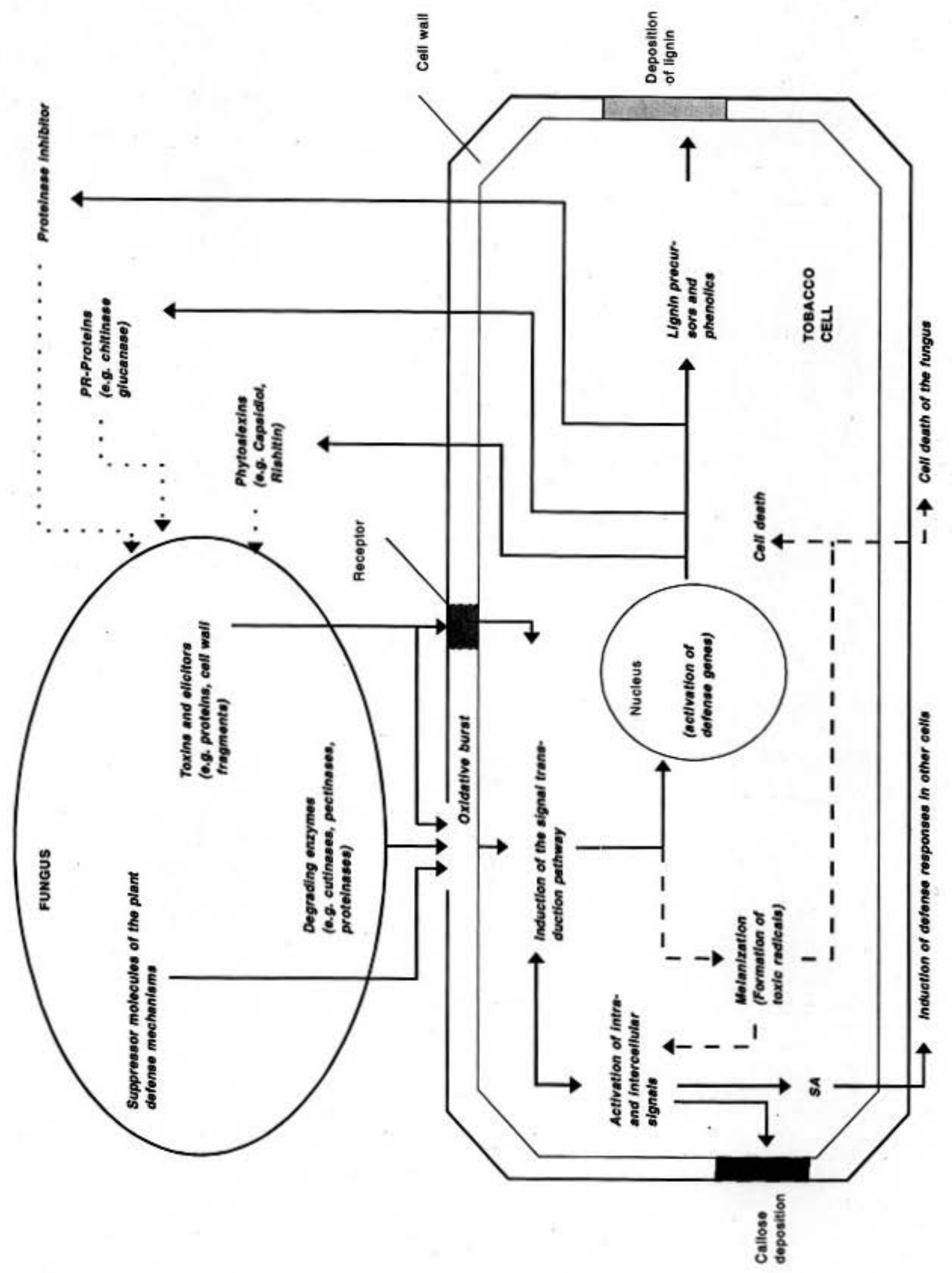

Figure 1.

Inducible defence mechanisms of the tobacco plant: Signals and responses in tobacco cell - fungal pathogen interactions.

: Pointed lines indicate inducible defense systems with toxic or growth inhibiting effects for the fungus;

(SA $\quad$ Salicylic acid). 
pathogens are capable of passing through this mechanical obstacle by secreting lytic enzymes (e.g. cutinases, pectinases, cellulases), as already mentioned above (15).

Other important cuticular components which also contribute to the expression of disease resistance are the fungitoxic diterpene exudates of the trichomes. These compounds (duvanes, labdanes) obviously inhibit sporangial germination and the growing of hyphae. They are leaf surface constituents of tobacco (44). According to its genotype, a tobacco species may synthesize one or both of these diterpene classes, showing quantitative and qualitative differences in the production of these cuticular compounds. Duvane-producing tobaccos yield a mixture of duvatrienols and duvatrienediols. The most important labdane diterpene synthesized is cis-abienol (27). In general, a high level of duvatrienediols on the leaf surface seems to impede colonisation by fungal spores (51). It has been reported in a recent study that glucose and sucrose esters secreted by leaf trichomes also exhibit antimicrobial activity (27).

Phenolic compounds such as eugenol, guaiacol or catechol also belong to the preformed constitutive defence system (50). They have been found in leaf tobacco cells. Watersoluble phenolic constituents of tobacco impair the germination of spores and seem to act as inhibitors of the lytic cell wall decomposing enzymes of the fungus. In particular, the highly sensitive SH-groups in the reaction centre are inactivated by phenols (28). However, biosynthesis of certain phenolic compounds (e.g. scopolin) can also be induced by infection with a fungal pathogen (37).

\subsubsection{Inducible defence mechanisms}

\section{Melanization}

Necrotic spots, the characteristic feature of $H R$, can be explained by the synthesis of brown and black pigments (melanins) in the collapsed cells. Plant melanins are polymers of different o-dihydroxyphenolic compounds. In tobacco, the prevailing dihydroxyphenols are chlorogenic acid and caffeic acid (50). Black and brown pigments are formed by the action of polyphenol oxidase (PPO) and peroxidase (PO). PPO seems to be responsible for the oxidation of phenol derivatives to o-quinones, whereas PO initiates the polymerisation of the reaction products (28). The extent of the melanization process often correlates with the intensity of the hypersensitive response. The enhanced activity of PPO and PO triggers the formation of toxic radicals, with detrimental effects not only for the fungal pathogen but also on the viability of the plant cells (Figure 1).

These reactive compounds can form unspecific linkages with cellular constituents of the pathogen and the host, leading to inactivation of enzymes and macromolecules.
As a result, the above-mentioned necrotic spots develop at the infection site. Melanized cell walls are much more stable against the hydrolytic activity of the fungal enzymes, thus constituting an additional barrier for a microbial pathogen.

\section{Integration of carbohydrates (callose) and structural proteins (extensins) into the cell wall structure.}

The colonization effort of a fungal pathogen can result in the biosynthesis of a specific class of polysaccharides in the tobacco plant. Particularly callose, (1,3-ß-D-glucan) and cellulose are formed at the initial sites of infection and deposited around the lesions by adjacent cells. Callose production involves the activation of a pre-existing callose synthetase at the plasma membrane by a second messenger (15). Deposition of the polysaccharide can already occur within minutes after applying of the stimulus and the newly synthesized callose is integrated into the plasma membrane - cell wall interface (47). This morphological barrier can prevent the systemic spread of the fungal hyphae or at least delay their expansion (Figure 1). However, these processes can lead to encapsulation of the parasite. In susceptible tobacco plants callose deposition is either rather weak or it does not occur at all (10).

In addition, plant-specific antimicrobial cell wall proteins are synthesized and integrated into the cellulose microfibrils. These hydroxyproline-rich glycoproteins often have an inhibitory effect on fungal growth, protecting the cell wall of the host against the lytic attack of microbial enzymes. The best-characterized hydroxyproline-rich glycoproteins are basic extensins, which are encoded by a small multigene family. In healthy tobacco plants, extensins are predominantly present in roots and relatively rare in stems and leaves (20). During flower formation or in response to wounding, infection and other stresses, a rapid synthesis of soluble extensin precursors in overground plant organs is induced (24). They become insolubilized within the cell wall due to the development of covalent cross-links to one another by peroxidase action, providing mechanical strength and impenetrability to tobacco cells. It is assumed that the accumulation of extensin molecules contributes to the expression of resistance against a microbial attack.

\section{Lignification}

An important process is the lignification of the surrounding, still healthy tissue at the site of infection, which additionally increases the mechanical strength of the tobacco cells. 'The lignin polymers of cell walls either substantially suppress further penetration of hyphae or they often kill the fungal organism by encapsulating it (28). Lignin is a complex, three-dimensional polymer arising from radical polymerisation of coniferyl, sinapyl and $p$ - 
coumaryl alcohols catalyzed by hydrogen peroxide and peroxidases (Figure 2). Lignin polymers are deposited between the cellulose microfibrils into the cell wall. The lignin monomer alcohols - also called monolignols - derive from cinnamic acid by subsequent hydroxylations, methylations and reduction steps. The particular monolignols are transported as water- soluble B-glycosid precursors to the sites of polymer biosynthesis. Specific $\beta$ glucosidases of the cell wall ensure the release of the lignin monomers for lignification (28). Enhanced activity of the key enzymes of lignin biosynthesis can be observed in tobacco cells adjacent to the penetration site. Resistant tobacco plants react by rapid induction of phenylalanine ammonia lyase $(\mathrm{PAL})$ and cinnamate 4 hydroxylase $(\mathrm{C} 4 \mathrm{H})$ $(12,25,28)$. Likewise, an increased activity of methyl transferase and peroxidase has been established. In tobacco, three distinct enzymes account for ortho-diphenolo-methyltransferase (MT) activity with different substrate specificities. The major enzyme of healthy plants is the isoform I (MT-I), preferentially expressed in vascular tissue. Tobacco cells treated with the elicitor megaspermin from Phytophthora megasperma realize the expression of the MT-II and MT-III genes (31), whereby a greater amount of monolignols for the lignification process can be supplied. Interestingly, increases in MT and peroxidase activity can be localized at the infection sites where the polymerisation to lignins reaches its highest level.

\section{Phytoalexins}

Tobacco phytoalexins are low molecular weight antimicrobial compounds, which are synthesized and accumulated in the plant after its exposure to microorganisms. The contact with an endogenous or exogenous elicitor initiates a local phytoalexin formation in living cells surrounding the necrotic spots. The majority of phytoalexin stress metabolites elicited in Nicotiana species are sesquiterpenoids. However, derivatives of the phenylpropanoid pathway (e.g. chlorogenic acid), can also accumulate during HR (45). In Nicotiana tabacum infected with Peronospora tabacina, antifungal sesquiter-

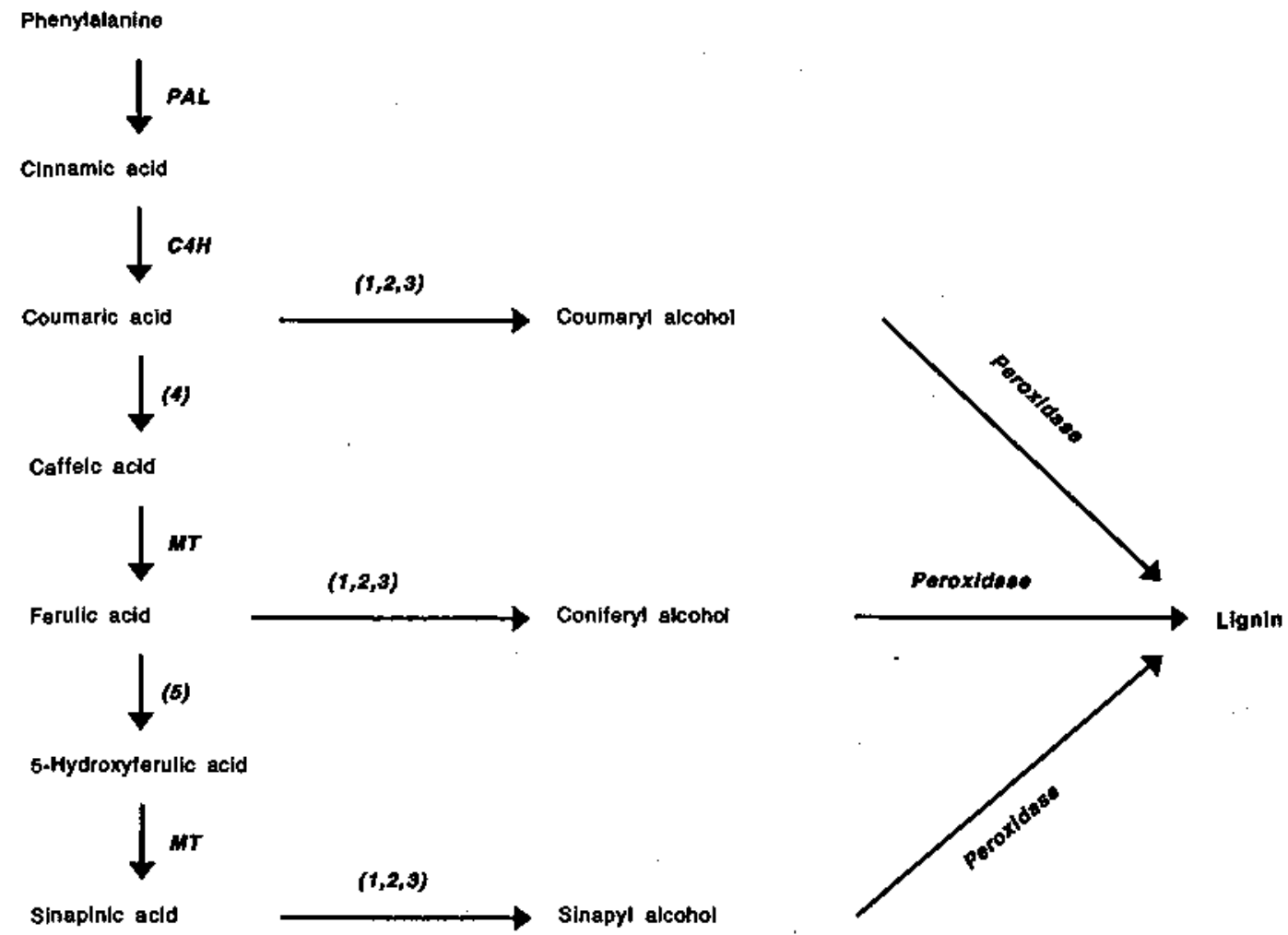

Figure 2.

Pathway for biosynthesis of phenylpropanoid lignin precursors elaborated from phenylalanine. Enzymes with enhanced activfties during the hypersensitive reaction are written in letters.

$\mathrm{C4H}=$ Cinnamic acid 4-hydroxylase; $\mathrm{PAL}=$ Phenylalanine ammonia lyase; $\mathrm{MT}=$ Methyl transferase

1 = CoA-ligase; 2 = CoA-reductase; 3 = Alcohol dehydrogenase; 4 = Coumanic acid hydroxylase; 5 = Ferulic acid hydroxylase 
penoid compounds such as capsidiol, phytuberol, phytuberin and rishitin are produced (46); the bicyclic sesquiterppenoid capsidiol accounts for approximately $50 \%$ of these fungitoxic plant metabolites. The metabolic pathway for the formation of phytoalexins parallels in various steps the biosynthetic pathway of sterols and other isoprenoids (Figure 3). Starting with acetyl-CoA, biosynthesis of sesquiterpene compounds proceeds via mevalonic acid and farnesyl diphosphate to capsidiol and other phytoalexin metabolites. Elicited tobacco cells show enhanced activity of 3-hydroxy-3-methyl-glutaryl CoA reductase (HMGR), a key enzyme of the isoprenoid pathway. Simultaneously, squalene synthetase activity is suppressed, resulting in a reduced accumulation rate of steroids $(3,49)$. A concomitant induction of sesquiterpene cyclase promotes a metabolite flow towards phytoalexin formation via the intermediate 5-epi-aristolochene (57). The modulation of sesquiterpene cyclase activity in tobacco seems to be effected by calcium or calcium-binding proteins (55). To- bacco plants attacked by a fungal pathogen possess the ability to accumulate large amounts of sesquiterpene phytoalexins in their leaves and roots. It has not yet been clarified satisfactorily why phytoalexins are fungitoxic. In most cases, the toxic principle seems to be interaction with membranes, especially the fungal plasmalemma, leading to impairment of its stability. The outflow of electrolytes and metabolites often observed as well as the swelling and bursting of hyphae can be attributed to this effect.

\section{Proteinase inhibitors (PI)}

The proteinase inhibitors of tobacco are small proteins or polypeptides with molecular weights of about 5,5-10,5 $\mathrm{kDa}(9,29,38)$. They seem to be an integral part of the plant defence system and are effective as growth inhibitors

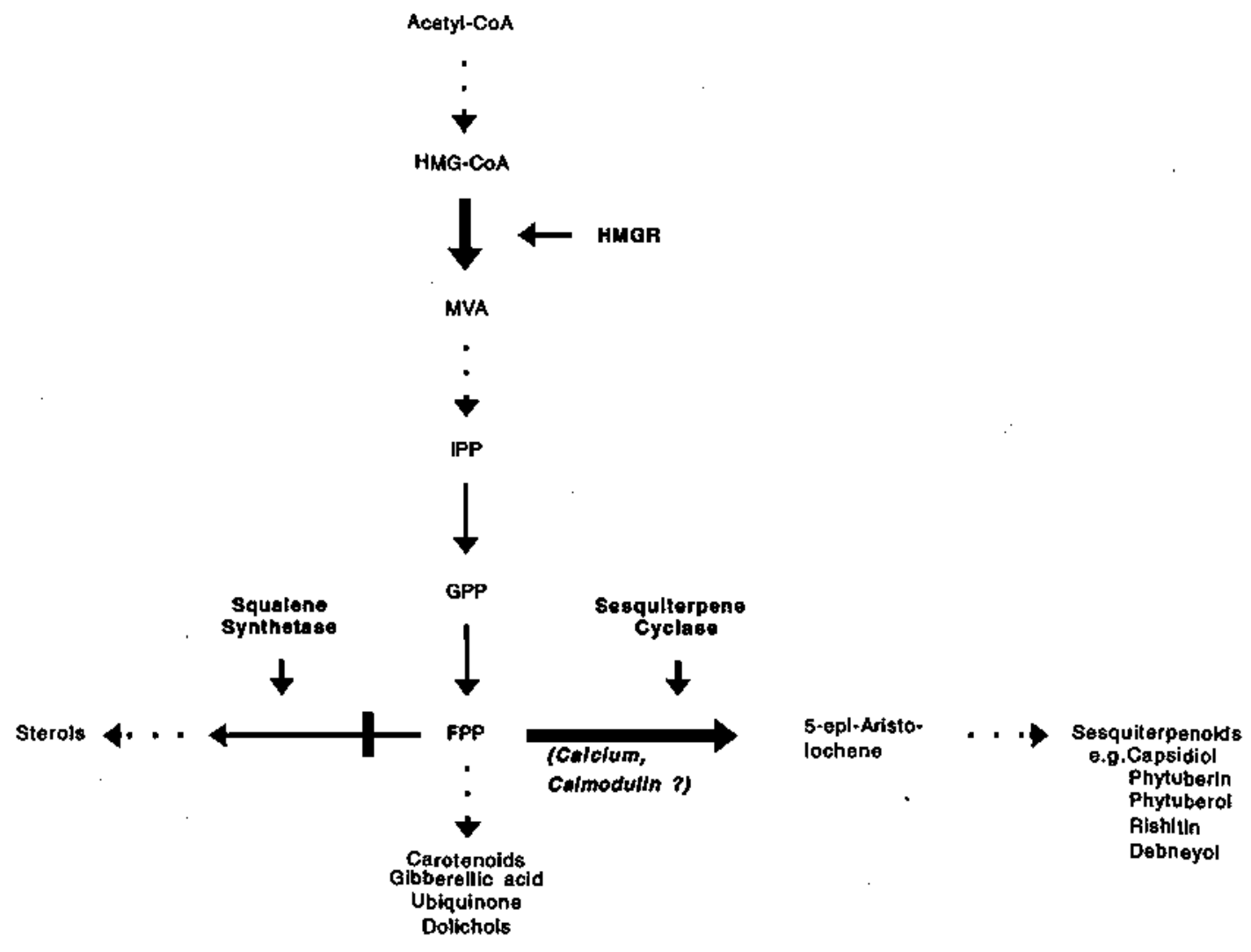

\section{Flgure 3.}

Regulation of the metabolic pathway leading to phytoalexin biosynthesis in tobacco.

Treatment of the tobacco cells with an fungal elicitor induces HMGR and sesquiterpene cyclase activities, whereas squalene synthetase activity undergoes a rapid decline. The rapid inhibition of squalene synthetase in elicited cultures may operate to channel FPP away from sterol biosynthesis towards 5-epi-aristolochene and the phytoalexins. Calcium or calmodulin-like proteins may be elements of a signal transduction pathway mediating the sesquiterpene cyclase catalyzed reaction to these antimicrobial compounds. Dashed lines indicate that not all steps and intermediates are shown. For further details, see text. FPP = Famesyl diphosphate; GPP= Geranyl diphosphate; HMG-CoA=3-Hydroxy-3-methylglutaryl COA; HMGR= 3-Hydroxy-3methylglutary $\mathrm{COA}$ reductase; IPP= Isopentenyl diphosphate; MVA= Mevalonate 
of hyphae, suppressing the activity of fungal proteinases. In this way enzymatic decomposition of plant proteins is prevented. Moreover, proteinases of insects and other microorganisms are also impaired in their function by tobacco PI. On the other hand, endogenous proteinases of plant origin undergo only slight reductions in their activity. There are two families of PI in tobacco (PI-I and PI-I) possessing different specificities against proteinases. In tobacco cells treated with an elicitor preparation from Phytopbthora parasitica var nicotianae, induction of PI occurs (38). The biosynthesis of these inhibitory acting molecules can also be observed after TMV-infection, salicylate treatment, ethephon spraying, UV light irradiation and wounding (18). After wounding, PI-I genes are coordinately expressed with the genes for the basic pathogenesis-related proteins. In contrast to other Solana. ceae plants (e.g. tomatoes, potatoes), wound induction of the tobacco genes occurs only locally. The healthy leaves do not show any wound-induced PI-I gene activation (18).

\section{Pathogenesis-related-proteins (PRP)}

After infection with a pathogen, elicitation of SAR involves the expression of genes encoding proteins with partly fungitoxic properties. The induction of the so-called pathogenesis-related proteins is a systemic defence response of tobacco to stop the penetration and proliferation of the microorganism locally and to protect uninfected tissue in distal parts of the plant. PRP are divided into five major groups based on serological properties and amino acid sequence data. For most of these five families differentially regulated acidic and basic isoforms have been reported (17). The biological activity and function of many PRP is still unknown. However, some of them possess hydrolytic properties and exert a decomposing effect on the cell wall polymers of numerous fungi (41). The major components of the sugar skeleton of many fungi are the polysaccharides chitin and $\beta-1,3$-glucan, substrates for chitinase and B-1,3-glucanase respectively. The lytic action of these enzymes in vitro has a suppressive effect on fungal growth. These observations, together with the assumption of an apparent lack of chitin in higher plants have led to speculation about a possible role for chitinases and B-1,3-glucanases in systemically induced resistance (Figure 1). In contrast to the rapid activation of the enzymes of callose or lignin biosynthesis during HR, the accumulation of chitinases and $1-1,3$ glucanases in the plant tissue is a slow process, which often reaches its maximum only after several days. Obviously, tobacco plants make use of various defence strategies, at different locations and times.

Signal molecules of the plant such as ethylene or salicylic acid seem to be involved in the induction mechanism of PRP. However, genes from the five PRP families are differentially regulated by the two plant hormones (17). Basic PRP-isoforms are induced at high levels by ethylene and wounding while the acidic proteins are not. In contrast, salicylate treatment induces most PRP genes to some extent, but biosynthesis of PR-1 proteins and the acidic PR-2 proteins is preferentially stimulated. By the effects of salicylic acid, members of the PRP-2 family, e.g. the acidic glucanase isoenzymes, are accumulated in the extracellular space. However, most of the basic PRP are deposited intracellularly into the vacuole.

In addition of the well-known function of some PRP in the development of resistance, certain PRP such as chitinase and B-1,3-glucanase also seem to be associated with morphogenetic changes in tobacco. PRP gene expression can be observed during flower formation of healthy plants, which suggests a role of these proteins in normal processes of development (24).

\section{INDUCTION AND REGULATION OF. THE INTRA- AND INTERCELLULAR SIGNAL TRANSDUCTION PATHWAY IN TOBACCO}

The mechanisms of the intra- and intercellular signal transduction for activating the various defence reactions (e.g. accumulation of phytoalexins, PRP, PI) are still poorly defined, and knowledge of these mechanisms is still very fragmentary.

It is evident that after contact of the tobacco cells with exogenous or endogenous elicitors, membrane depolarization of the plasmalemma occurs within seconds and is reversible (30). Changes in the membrane potential may be attributd to interaction of the elicitor with a specific membrane receptor. Other modes of action, however, such as disruption of membrane integrity by integration into the membrane or penetration and toxification of the cell should also be considered (42). A very rapid reaction of the tobacco cell triggered by a fungal elicitor is the stimulation of inositol phospholipid turnover and the activation of protein kinases (13). Alterations of the plasma membrane lipid composition can already be observed two minutes after elicitation. The enhanced activity of membrane-bound phosphatidylinositol kinase promotes biosynthesis of inositol 1,4-bisphosphate and inositol 1,4,5-trisphosphate which are suggested to be involved in the mobilisation and regulation of intracellular calcium pools and the modulation of ATPase activity in the plasma membrane (12).

The chemical composition and properties of the plant plasmalemma are fundamentally changed during the following minutes and hours. Analysis of the various sterol lipid classes reveals an increase in the levels of acylated sterol glycosides, whereas the content of free sterols, sterol esters, sterol glycosides and galactolipids are found to 
decrease in elicited cells (23). Simultaneously, lipoxygenase activity undergoes rapid and transient changes. Stimulation of the key enzyme of lipid peroxidation is detectable after $1,5 \mathrm{~h}$ and reaches a maximum after $24 \mathrm{~h}$ (39). In an incompatible interaction between host and parasite, the observed reaction is localized at the site of infection. Lipoxygenase catalyses the dioxygenation of numerous polyunsaturated fatty acids of the plasma membrane (e.g. linoleic, linolenic and arachidonic acids), and promotes the formation of reactive oxygen species and hydroperoxides. It is suggested that the enzyme is involved in the development of local cell necrosis during $\mathrm{HR}$, thereby impairing further penetration of the pathogen into the tissue. Moreover, some authors assume an influence of the enhanced lipoxygenase activity on jasmonic acid biosynthesis. Jasmonic acid is known to have regulatory properties in plant growth and in modulating the induction of proteinase inhibitors (8).

It is evident that these changes of the membrane potential and plasmalemma lipid composition can result in modification of the membrane-bound enzymes, but membrane permeability and the activity of ions and biomolecules of the cytosol are also influenced. Five minutes after treatment of tobacco cells with the elicitor cryptogein, increased effluxes of potassium ions into the extracellular medium can already be observed (54). The phosphorylation status of proteins involved in signal transduction and resistance development rises at the same time. In addition, calcium ion influxes across the plasma membrane have been established (33). The rapid influx of calcium, as well as the intracellular mobilisation of calcium pools by inositol phospholipids, is of decisive significance for the induction of the defence systerns. The studies by Raz and Fluhr (36) support the hypothesis that enhanced calcium levels in tobacco cells, together with a calmodulin-like factor, activate protein kinases (33). The protein phosphorylation resulting from this seems to trigger the defence mechanisms. Nevertheless, an alternative calcium independant pathway for the expression of PRP genes and the formation of further factors mediating resistance, has also been proposed (36). The sudden increase of reactive oxygen species 10-20 minutes after elicitor treatment may possible be an indicator for a calcium-independent induction of resistance genes. This reaction is known as "oxidative burst" and is generally of short duration. As a result, highly reactive oxygen species are generated at the infection sites which have a toxic effect on pathogens. It is furthermore suggested that elevated levels of active oxygen species such as $\mathrm{H}_{2} \mathrm{O}_{2}$ promote lignification of cell walls and the crosslinking of cell wall proteins, which inhibits penetration of a fungus. However, it has been assumed that low concentrations of active oxygen molecules act as second messengers for gene expression of PRP, $\mathrm{PI}$ and the enzymes of phytoalexin biosynthesis $(1,4)$. In contrast to the high levels required for pathogen killing during the oxidative burst, more moderate levels of reactive oxygen and free radicals can be detected at a later stage of signal transduction. These active oxygen species, which are certainly toxic at high concentrations, must now be considered true secondary messengers when present at lower concentrations, with the ability to induce $\mathrm{SAR}$. Chen at al. recently revealed sequence homologies of a salicylic acid binding protein with $\mathrm{H}_{2} \mathrm{O}_{2}$ deactivating catalases (4). As already shown by "in vitro" tests, salicylic acid binding protein possess $\mathrm{H}_{2} \mathrm{O}_{2}$ degrading activity. The results of the experiments suggest an inhibition of catalase activity by binding of SA to salicylic acid binding protein. This causes elevated amounts of hydrogen peroxide to accumulate in the tobacco cells. However, a calcium dependent activation of defence genes by reactive oxygen species cannot be excluded, as shown by Price et al. (34). These authors observed an increase of cytosolic $\mathrm{Ca}^{2+}$ levels elicited by treatment with hydrogen peroxide.

As already mentioned, moderate levels of active oxygen species lead to the expression of PRP genes. For this reason it can be speculated that salicylic acid signal transduction via $\mathrm{H}_{2} \mathrm{O}_{2}$ acts as a second messenger in establishing an SAR response in distal tissues. However, the role of salicylic acid seems to be of great significance for the manifestation of SAR, since uninfected parts of the plant develop increased resistance to further infections by viral, bacterial and fungal pathogens after salicylate treatment. Following inoculation with a pathogen, local and systemic increases in SA levels can be stimulated in the tissue of Nicotiana species $(4,43)$. Many authors assume that SA moves as a phloem-transmissible signal from the site of initial pathogen infection throughout the plant, inducing SAR in distal tissue. The results of Vernooij et al. (53), however, indicate that the translocating, SARinducing signal is not salicylate. Reciprocal grafts demonstrate that transgenic tobacco rootstocks, although unable to accumulate salicylic acid, are fully capable of delivering a signal that renders nontransgenic scions resistant to further pathogen infection.

A further signal molecule of presumably great significance for the manifestation of a defence response is ethylene. The gaseous plant hormone regulates many physiological processes in plants and is also produced in tissues undergoing HR (7). Ethylene subsequently induces a multitude of gene arrays believed to play a role in plant defence. Sensitivity to ethylene is probably mediated by a specific receptor whose activation signal is then transduced via an unknown cascade pathway. Ethylene rapidly stimulate protein phosphorylation in tobacco cells (36). It controls cytosolic calcium levels (35), affects the lignification process and the accumulation of cell wall cross-linking hydroxyproline-rich glycoproteins (extensins) and induces PRP synthesis $(7,21,43)$. Nevertheless, several studies indicate no direct involvement of ethylene in the signal transduction pathway. The expression of SAR genes 
seems to be controlled by an ethylene-independent signaltransducing mechanism, too $(36,43)$. Thus ethylene is considered to be a non-essential factor for the manifestation of resistance and serves as stress symptom rather than a signal in the induction of defence responses. On the other hand, one can speculate about a possible role of the gaseous molecule in promotion and stimulating protection mechanisms of healthy plants in the direct neighbourhood of the infected tobacco.

Completely unknown is the function of tobacco glycinrich proteins GRP, which accumulate during pathogenesis in plant tissue. Fifteen minutes after contact of a glucan elicitor with the tobacco cell, elevated GRP gene mRNA levels can already be detected (2). It is assumed that GRP gene expression is involved in the regulation of plantpathogen interactions $(2,17)$.

Very little information concerning the activity and biological significance of transposons during $H R$ has been accumulated up to now. It has recently been shown that Tnt 1 retrotransposon expression can be induced by cryptogein and capsicein treatment of the plant (32). Tobacco cells synthesize high levels of Tnt 1 RNA in the necrotic areas two hours after contact with an elicitor. This accumulation of Tnt 1 RNA correlates with the phytoalexin capsidiol a few hours later. Pouteau et al. conclude that the activation of a Tnt 1 retrotransposon reflects local and early plant response to microbial stress. However, it is not clear what relevance this may have for the signal transduction chain leading to SAR. The assumption that high levels of Tnt 1 RNA may contribute to local cell death during HR has been discussed. Alternatively, Tnt 1 activation could be a general response of the organism to genomic stress, forcing the genome to restructure itself in order to survive stress situations by inducing transposable elements (32).

A general view of important components of the tobacco plant defence system against fungal pathogens is presented in Figure 1.

Further developments on signal transduction in tobacco will be discussed in a forthcoming paper.

\section{PERSPECTIVES}

Pathogenesis-related proteins, phytoalexins and proteinase inhibitors are natural fungicides of tobacco. Together with structural resistance factors, constitutive chemical defence compounds, as well as additional inducible protection systems (e.g. lignification, callose biosynthesis) they can cause resistance against fungal pathogens. The multitude of defence strategies and their realisation at different spatial and temporal levels require a common, exactly balanced cooperation of all systems in order to ensure adequate protection. Considerable progress has been made in recent years in investigating the molecular interactions between pathogen and host plant and defining the mechanisms involved in the elaboration of defence responses. These advances in our knowledge of disease resistance mechanisms may form the basis for biotechnological applications in agriculture $(16,48)$. Strategies are emerging for manipulating and modifying inducible defence systems leading to the biosynthesis of natural fungicides in tobacco. These chemical compounds and constituents of the cell could represent a new and effective generation of pesticides, toxicologically harmless for the environment and for man. In the past, the majority of the fungicides generally used for plant protection were synthetic products of great persistence. Nowadays the requirements for good and effective pesticides are almost the exact opposite. The typical characteristics of current and particularly of future pesticides are easy degradability, low environmental impact and a high specificity against parasites and pathogenic fungi. The lastnamed requirements are fulfilled by the natural fungicides synthesized during an incompatible interaction between host and microorganism. Beside recombinant DNA technologies, new classes of agrochemicals with the potential to act as inducers of natural resistance mechanisms offer alternative strategies for manipulation of natural defence systems in tobacco. In addition, genetic modifications of the plant genome permit the simplification of plant breeding procedures, which enables a quicker establishment of resistant tobacco species. Extensive studies to utilize these new techniques have already been carried out. Some of the successfully tested biotechnological strategies for modifying tobacco plants will be presented in the following sections:

- One strategy is to express in a constitutive fashion the genes for chitinase and B-1,3-glucanase activity, normally induced as a result of pathogen attack $(16,48)$. A high level of constitutive expression of a chitinase transgene in tobacco has already been achieved. However, effective protection against a fungal pathogen seems to be ensured only by a combined induction of both genes. Obviously, chitinase and B-1,3-glucanase enzymes can act synergistically, resulting in lysis of the hyphal tips and growth inhibition (41).

- The genetic transfer of ribosome-inactivating proteins (RIP) from barley into the tobacco plant offer another possible approach for interfering specifically with fungal metabolism $(16,48)$. RIP inhibit protein synthesis by $\mathrm{N}$-glycosidic cleavage of $28 \mathrm{~S}$ rRNA. However, RIP do not inactivate plant ribosomes, but show inhibitory activity towards ribosomes from distantly related species including fungi. These findings were used by Logemann et al. (19), who reported measurable protection against Rhizoctonia solani for transgenic tobaccos expressing a barley seed 
RIP gene under control of a wound-inducible promoter.

- Transgenic tobacco plants with enhanced anionic peroxidase activity show a substantial increase in resistance to Peronospora parasitica (16). Furthermore, Mohan et al, reported induction of a tomato anionic peroxidase gene in transgenic tobacco by inoculation with fungal conidia from Fusarium solani (22). As already mentioned, plant peroxidases have been implicated in important defence processes such as melanization, lignification and extensin cross-linking.

- The manipulation of multigenic defence mechanisms such as phytoalexin biosynthesis or lignin deposition seems to be promising. A precondition for an enhanced expression of such multigenic defences is the identification of regulatory genes or the key enzyme of the rate determining step. By modifying the expression of a single gene encoding a regulatory enzyme it should be possible to alter flux through such a multistep metabolic pathway, thereby intensifying the biological activity of the pathway products (16).

- A further attractive strategy for enhancing resistance is the confrontation of a fungal pathogen with unfamiliar phytoalexins $(16,48)$. Tobacco plants contain the precursors for the formation of stilbene phytoalexins, but lack the enzyme stilbene synthase. After transfer of a stilbene synthase gene from the grapevine to tobacco, transgenic plants express the foreign gene in response to inoculation with Botrytis cinerea (11). Consequently, the fungitoxic phytoalexin resveratrol is synthesized by stilbene synthase action and accumulates in tobacco tissue. Nevertheless, a persistent constitutive expression of such a resistance gene could result in high phytoalexin concentrations in the cells. Many phytoalexins are themselves phytotoxic and their widespread accumulation may therefore have deleterious effects on responding tissues. It is therefore desirable to activate the appropriate phytoalexin gene only after contact with the fungus.

- The expression of capsicein and related elicitin proteins in transgenic tobacco may provide new approach to engineering protection (16). Elicitins are known to cause systemic remote leaf necrosis but also elicit the accumulation of PRP and phytoalexins and induce protection against subsequent inoculation with the tobacco pathogen Phytophthora nicotianae $(16,58)$. Moreover, the transfer of a soybean $B-1,3-$ endoglucanase gene into tobacco and its expression seems to stimulate resistance of transgenic tobacco against this fungal pathogen in a similar way (58).

An alternative approach focuses on proteinase inhibitors - The inactivation of proteinases of animal or fungal origin by the expression and activity of foreign PI in transgenic tobacco might be a potent tool to improve plant resistance $(5,9)$.

- There are new techniques in plant protection which do not require genetic engineering of the tobacco genome. Some classes of chemical compounds have the potential to act as inducers of natural resistance mechanisms and offer attractive alternatives or additions to existing fungicides (5). Spraying plants with agrochemicals possessing the biological functions of signal molecules such as salicylic acid, jasmonic acid or ethylene can induce SAR. A synthetic inducer of protection which can mimic the immunising effect of salicylic acid is 2,6-dichloroisonicotinic acid (INA). INA has a molecular shape similar to that of salicylic acid and activates the same set of SAR-genes as plants sprayed with salicylic acid. A commercial application of INA is promising, since the salicylic acid analogue offers optimum conditions for the plant to resist fungal attack. In comparison, the utilisation of salicylic acid as a plant protective in agriculture seems not to be favorable. Healthy plants metabolize the compound so quickly that the induced resistance is only short-lived and confined to the sprayed leaves (5).

The studies of the utilisation of the plant's own defence strategies for protection against fungal pathogens and other microorganisms are very encouraging. Recombinant DNA techniques are not the only ones now available to complement traditional efforts to breed resistant varieties and to control disease development. Spraying of synthetic signal compounds (e.g. INA) which mimic natural inducers of plant defence responses, has also produced astonishing results. Nevertheless the biochemical and molecular genetic elements of plant resistance are poorly understood. Prospective investigations of the regulatory processes used by plants to transduce environmental signals and of the biosynthetic pathways of natural fungicides in tobacco will certainly call attention to further alternatives for the control of fungal diseases. Perhaps these new methods will be able to complement conventional techniques and strategies in plant protection, or even replace them completely in the foreseeable future.

\section{Abbrevlatlons: \\ $\mathrm{C} 4 \mathrm{H}$ \\ FPP \\ GPP \\ = Cinnamate 4-hydroxylase; \\ = Farnesyl diphosphate; \\ =' Geranyl diphosphate;}




$\begin{array}{ll}\text { GRP } & =\text { Glycin-rich proteln; } \\ \text { HMG-CoA= } & \text { 3-Hydroxy-3-methylglutaryl CoA } \\ \text { HMGR } & \text { 3-Hydroxy-3-methylglutaryl CoA reductase; } \\ \text { HR } & =\text { Hypersensitive response; } \\ \text { INA } & =2,6-\text {-Dichloroisonicotinic acid; } \\ \text { IPP } & =\text { Isopentenyl diphosphate; } \\ \text { MT } & =\text { Methyl transferase; } \\ \text { MVA } & =\text { Mevalonate; } \\ \text { PAL } & =\text { Phenylalanine ammonia lyase; } \\ \text { PI } & =\text { Proteinase inhibitor; } \\ \text { PO } & =\text { Peroxidase; } \\ \text { PPO } & =\text { Polyphenol oxidase; } \\ \text { PRP } & =\text { Pathogenesis related proteins; } \\ \text { RIP } & =\text { Ribosome-inactivating protein; } \\ \text { SA } & =\text { Salicylic acid; } \\ \text { SAR } & =\text { Systemic acquired resistance. }\end{array}$

\section{REFERENCES}

1. Bottin, A., Véronési, D., Esquerré-Tugayé, M.T., Blein, J.-P., Rusterucci,C. and P. Ricci: Differential responses of tobacco cells to elicitors from two Phytophtbora species; Plant Physiol. Biochem. 32 (1994) 373-378.

2. Brady, K.P., Darvill, A.G. and P. Albersheim: Activation of a tobacco glycine-rich protein gene by a fungal glucan preparation; Plant J. 4 (1993) 517-524.

3. Chappell, J., VonLanken, C. and U. Vögeli: Elicitorinducible 3-hydroxy-3-methylglutaryl coenzyme A reductase activity is required for sesquiterpene accumulation in tobacco cell suspension cultures; Plant Physiol. 97 (1991) 693-698.

4. Chen, Z., Silva, H. and D.F. Klessig: Active oxygen species in the induction of plant systemic acquired resistance by salicylic acid; Science 262 (1993) 18831886.

5. Day, S.: A shot in the arm for plants; N. Scientist 1855 (1993) 36-40.

6. Edreva, A., Karjieva, R., Coussirat, J.C., Lukarska, E. and R. Delon: Involvement of free radicals and superoxide dismutase in blue mold resistance of tobacco; Ann. du Tabac 23 (1991) 69-74.

7. Enyedi, A.J., Yalpani, N., Silverman P. and J. Raskin: Signal molecules in systemic plant resistance to pathogens and pests; Cell 70 (1992) 879-886.

8. Fournier, J., Pouénat, M.-L., Rickauer, M. Rabinovitch-Chable, H., Rigaud, M. and M.'T. Esquerré Tugayé: Purification and characterisation of elicitor-induced lipoxygenase in tobacco cells; Plant J. 3 (1993) 63-70.

9. Geoffroy, P., Legrand, M. and B. Fritig: Isolation and characterization of a proteinaceous inhibitor of microbial proteinase induced during the hypersensitive reaction of tobacco to tobacco mosaic virus; Mol. Plant Microbe Interact. 3 (1990) 327-333.
10. Georgieva, I.D., Delon, R., Coussirat, J.C. and A. Edreva: Erude biochimique du tabac éprouvé dans les conditions du test cotylédons: effet du magnésium, réactions des plantes résistentes et sensibles à Perono. spora tabacina VII. Etude cytochimique de la callose; Ann. du Tabac 22 (1989) 95-101.

11. Hain, R., Reif, H.-J., Krause, E., Langebartels, R., Kindl, H., Vornam, B., Wiese, W., Schmelzer, E., Schreier, P.H., Stökker, R.H. and K. Stenzel: Disease resistance results from foreign phytoalexin expression in a novel plant; Nature 361 (1993) 153-156.

12. Kamada, Y. and S. Muto: Stimulation by fungal elicitor of inositol phospholipid turnover in tobacco suspension culture cells; Plant Cell Physiol. 35 (1994) 397-404.

13. Kamada, Y. and S. Muto: Proteine kinase inhibitors inhibit stimulation of inositol phospholipid turnover and induction of phenylalanine ammonia-lyase in fungal elicitor-treated tobacco suspension culture cells; Plant Cell Physiol. 35 (1994) 405-409.

14. Kamoun, S., Young, M., Glascock, C.B. and B.M. Tyler: Extracellular protein elicitors from Phytophthora: Host-specificity and induction of resistance to bacterial and fungal phytopathogens; Mol. Plant Microbe Interact. 6 (1993) 15-25.

15. Lamb, C.J., Lawton, M.A., Dron, M. and R.A. Dixon: Signals and transduction mechanisms for activation of plant defenses against microbial attack; Cell 56 (1989) 215-224.

16. Lamb, C.J., Ryals, J.A., Ward, E.R. and R.A. Dixon: Emerging strategies for enhancing crop resistance to microbial pathogens; Biotechnol. 10 (1992) 1436-1445.

17. Linthorst, H.J.M.: Pathogenesis-related proteins of plants; Critical Reviews in Plant Sciences 10 (1991) 123-150.

18. Linthorst, H.J.M., Brederode, F.T., van der Does, C. and J.F. Bol: Tobacco proteinase inhibitor-I genes are locally, but not systemically induced by stress; Plant Mol. Biol. 21 (1993) 985-992.

19. Logemann, J., Jach, G., Tommerup, H., Mundy and J. Schell: Expression of a barley ribosome-inactivating protein leads to increased fungal protection in transgenic tobacco plant; Biotechnol. 10 (1992) 305308.

20. Memelink, J., Hoge, J.H.C. and R.A. Schilperoort: Cytokinin stress changes the development regulation of several defence-related genes in tobacco; EMBO J. 6 (1987) 3579-3583.

21. Memelink, J., Swords, K.M.M., de Kam, R.J., Schilperoort, R.A., Hoge, J.H.C. and L.A. Staehelin: Structure and regulation of tobacco extensin; Plant $\}$. 4 (1993) 1011-1022. 
22. Mohan, R., Bajar, A.M. and P.E. Kolattukudy: Induction of a tomato anionic peroxidase gene (tap 1) by wounding in transgenic tobacco and activation of tap 1/GUS and tap 2/GUS chimeric gene fusions in transgenic tobacco by wounding and pathogen attack; Plant Mol. Biol. 21 (1993) 341-354.

23. Moreau, R.A., Powell, M.J., Whitaker, B.D., Baily, B.A. and J.D. Anderson: Xylanase treatment of plant cells induces glycosylation and fatty acylation of phytosterols; Physiol. Plant. 91 (1994) 575-580.

24. Neale, A.D., Wahleithner, J.A., Lund, M., Bonnett, H.T., Kelly, A., Meeks-Wagner, D.R., Reacock, W.J. and E.S. Dennis: Chitinase, B-1,3-glucanase, osmotin, and extensin are expressed in tobacco explants during flower formation; Plant Cell 2 (1990) 673-684.

25. Nemestothy, G.S. and D.I. Guest: Phytoalexin accumulation, phenylalanine ammonia lyase activity and ethylene biosynthesis in fosetyl-Al treated resistant and susceptible tobacco cultivars infected with Phytophthora nicotianae var. nicotianae; Physiol. Mol. Plant Pathol. 37 (1990) 207-219.

26. Nesopoulos, C. and J.-C. Pernollet: Local structural differences between $\alpha$ - and $\beta$-elicitins by circular dichroism and ultraviolet difference spectroscopy; Int. J. Pept. Protein Res. 43 (1994) 154-159.

27. Nielsen, M.: Leaf Surface compounds affecting germination of Peronospora tabacina sporangia. CORESTA Information Bulletin 4 (1991) 156.

28. Oßwald, W. and E.F. Elstner: Die Wirt-Parasit-Beziehungen, Bakterien und Pilze als Parasiten; in Schadwirkungen auf Pflanzen, edited by B. Hock and E.F. Elstner, B.I.Wissenschaftsverlag, Mannheim, 1988, p. 251.

29. Pearce, G., Johnson, S. and C.A. Ryan: Purification and characterization from tobacco (Nicotiana tabacum) leaves of six small, wound-inducible, proteinase isoinhibitors of the potato inhibitor II family; Plant Physiol. 102 (1993) 639-644.

30. Pélissier, B., Thibaud, J., Grignon, C. and M.-T. Esquerré-Tugayé: Cell surfaces in plant-microorganism interactions. IV. Elicitor preparations from fungal pathogens depolarize plant membranes; Plant Sci. 56 (1986) 103-109.

31. Pellegrini, L., Geoffroy, P., Fritig, B. and M. Legrand: Molecular cloning and expresssion of a new class of ortho-diphenol-o-methyltransferases induced in tobacco (Nicotiana tabacum $L$.) leaves by infection or elicitor treatment; Plant Physiol. 103 (1993) 509-517.

32. Pouteau, S., Grandbastien, M.-A. and M. Boccara: Microbial elicitors of plant defence responses activate transcription of a retrotransposon; Plant J. 5 (1994) 535-542.

33. Preisig, C.L. and R.A. Moreau: Effects of potential signal transduction antagonists on phytoalexin accumulation in tobacco; Phytochem. 36 (1994) 857-863.
34. Price, A.H., Taylor, A., Ripley, S.J., Griffiths, A., Trewavas, A.J. and M.R. Knight: Oxidative signals in tobacco increase cytosolic calcium; Plant Cell 6 (1994) 1301-1310.

35. Raz, V. and F. Fluhr: Calcium requirement for ethylene-dependent responses; Plant Cell 4 (1992) 1123-1130.

36. Raz, V. and R. Fluhr: Ethylene signal is transduced via protein phosphorylation events in plants; Plant Cell 5 (1993) 523-530.

37. Reuveni, M. and Y. Cohen: Growth retardation and changes in phenolic compounds with special reference to scopoletin in mildewed and ethylene-treated tobacco plants; Physiol. Plant Pathol. 12 (1978) 179-189.

38. Rickauer, M., Fournier, J.and M.-T. Esquerré-Tugayé: Induction of proteinase inhibitors in tobacco cell suspension culture by elicitors of Phytophthora parasitica var. nicotianae; Plant Physiol. 90 (1989) 10651070.

39. Rickauer, M., Fournier, J., Pouénat, M.-L., Berthalon, É., Bottin, A. and M.-T. EsquerréTugayé: Early changes in ethylene synthesis and lipoxygenase activity during defense induction in tobacco cells; Plant Physiol. Biochem. 28 (1990) 647-653.

40. Sanchez, L.M., Doke, N. and K. Kawakita: Elicitorinduced chemiluminescence in cell suspension cultures of tomato, sweet pepper and tobacco plants and its inhibition by suppressor from Phytophthora spp.; Plant Sci. 88 (1993) 141-148.

41. Sela-Buurlage, M.B., Ponstein, A.S., Bres-Vloemans, S.A., Melchers, L.S., van den Elzen, P.J.M. and B.J.C. Cornelissen: Only specific tobacco (Nicotiana tabacum) chitinases and B-1,3-glucanases exhibit antifungal activity; Plant Physiol. 101 (1993) 857-863 .

42. Sharon, A., Fuchs, Y. and J.D. Anderson: The elicitation of ethylene biosynthesis by a Trichoderma xylanase is not related to the cell wall degradation activity of the enzyme; Plant Physiol. 102 (1993) 1325-1329.

43. Silverman, P., Nuckles, E., Ye, Y.S., Kuc, J. and J. Raskin: Salicylic acid, ethylene, and pathogen resistance in tobacco; Mol. Plant Microbe Interact. 6 (1993) 775-781.

44. Sisson, V.A., Severson, R.F. and D.M. Jackson: Inheritance of high duvatrienol production in tobacco; Tob. Sci. 37 (1993) 25-29.

45. Snook, M.E., Chortyk, O.T. and A.S. Csinos: Black shank disease fungus; Inhibition of growth by tobacco root constituents and related compounds; in Naturally occurring pest bioregulators, edited by P.A. Hedin, ACS Symposium Series 449, Washington, 1991, pp. 388-398. 
46. Stolle, K., Zook, M., Shain, L. and J. Kuc: Restricted colonization by Penonospora tabacina and phytoalexin accumulation in immunized tobacco leaves; Phytopathol. 78 (1988) 1193-1197.

47. Stone, B.A: Cell walls in plant-microorganism associations; Aust. J. Plant Physiol. 16 (1989) 5-17.

48. Strittmatter, G. and D. Wegener: Genetic engineering of disease resistance in plants: present state of art; $Z$. Naturforsch. 48c (1993) 673-688.

49. Threlfall, D.R. and I.M. Whitehead: Co-ordinated inhibition of squalene synthetase and induction of enzymes of sesquiterpenoid phytoalexin biosynthesis in cultures of Nicotiana tabacum; Phytochem. 27 (1988) 2567-2580.

50. Tso, T.C.: Production, physiology and biochemistry of tobacco plant; IDEALS, Inc., Beltsville, Maryland, USA 1990 , p. 550.

51. Tuzun, S., Reuveni, M., Siegel, M.R. and J. Kuc: The effect of removing leaf surface components with acetone from immunized and nonimmunized resistant tobacco plants on their susceptibility to blue mold; Phytopathol. 79 (1989) 1024-1027.

52. Van Etten, H.D., Matthews, D.E. and P.S. Matthews: Phytoalexin Detoxification: Importance for pathogenicity and practical implications; Ann. Rev. Phytopathol. 27 (1989) 143-164.

53. Vernooij, B., Friedrich, L., Morse, A., Reist, R., Kolditz-Jawhar, R., Ward, E., Uknes, S., Kessmann, $H$, and J. Ryals: Salicylic acid is not the translocated signal responsible for inducing systemic acquired resistance but is required in signal transduction; Plant Cell 6 (1994) 959-965.
54. Viard, M.-P., Martin, F., Pugin, A., Ricci, P. and J.-P. Blein: Protein phosphorylation is induced in tobacco cells by the elicitor cryptogein; Plant Physiol. 104 (1994) 1245-1249.

55. Vögeli, U., Vögeli-Lange, R. and J. Chappell: Inhibition of phytoalexin biosynthesis in elicitortreated tobacco cell-suspension by calcium/calmodulin antagonists; Plant Physiol. 100 (1992) 13691376.

56. Waffenschmidt, S. and L. Jaenecke: Glykoproteine und Pflanzen-Zellkommunikation; Chemie in unserer Zeit 1 (1991) 29-43.

57. Whitehead, I.M., Threlfall, D.R. and F. Ewing: 5-epiaristolochene is a common precursor of the sesquiterpenoid phytoalexins capsidiol and debneyol; Phytochem. 28 (1989) 775-779.

58. Yoshikawa, M., Tsuda, M. and Y. Takeuchi: Resistance to fungal diseases in transgenic tobacco plants expressing the phytoalexin elicitor-releasing factor, B-1,3-endoglucanase, from soybean; Naturwissenschaften 80 (1993) 417-420.

59. Zanetti, A., Beauvais, F., Huet, J.-C. and J.-C. Pernollet: Movements of elicitins, necrosis-inducing proteins secreted by Phytophthora sp., in tobacco; Planta 187 (1993) 163-170.

Author's address

Verband der Cigarettenindustrie

Wissenschaftliche Abteilung

Königswinterer Straße 550

53227 Bonn 